\title{
Tissue characterization by photographic imaging during treatment of chronic venous ulcer: technical note
}

\author{
Caracterização tecidual de imagem fotográfica durante tratamento de \\ úlcera venosa crônica: nota técnica \\ Fernanda Thaysa Avelino dos Santos', Camila Ataíde Rocha', Sergio Xavier Salles Cunha', \\ Thays Fernanda Avelino dos Santos', Charles Hamilton Mélo Júnior', Jéssika Medeiros de Barros Lima', \\ Adriana Melo Barbosa Costa', Guilherme Benjamin Brandão Pitta ${ }^{1}$
}

\begin{abstract}
Chronic venous ulcers are a medical challenge with a socioeconomic impact. Tissue characterization was quantified by photographic imaging ( $p$-CATIM) of a leg wound treated with Unna boot for 45 days. Three photographs, taken pre-treatment, post Unna boot and post healing were analyzed. Brightness on a 0-255 gray image was re-scaled with black as 0 and adjacent skin as 200. Gray Scale Median (GSM) and the percentages of pixels in each of 14 brightness intervals were calculated. Open ulcer GSM increased from 110 to 159 post Unna boot treatment, reaching 203 post healing. Predominant brightness intervals for the ulcer were 41-153 pre-treatment, 83\% of pixels; 133-196 post Unna boot, 80\%; and 175-255 post healing, 97\%. The GSM of the subcutaneous wound around the ulcer increased from 117 to 137 post healing; the proportion of pixels in the $91-174$ interval increased from $67 \%$ to $88 \%$ ( $p<0.001$ ). CATIM quantified photographic changes during venous ulcer healing with comparison to the adjacent skin.
\end{abstract}

Keywords: venous insufficiency; ulcer; photography; quantitative analysis; healing.

\begin{abstract}
Resumo
Úlcera de estase na insuficiência venosa crônica constitui desafio médico com impacto socioeconômico. Quantificamos caracterização tecidual por imagem fotográfica (f-CATIM) em ferida de perna tratada com bota de Unna por 45 dias. Três fotografias obtidas pré-tratamento, pós-tratamento com bota e pós-cicatrização foram analisadas. Brilhos em imagem cinza foram recalculados para nova escala no zero preta e 200 para brilho de pele adjacente à ferida. Mediana da escala cinza ou Gray Scale Median (GSM) e proporções de pixels em 14 intervalos de brilho foram estimadas. GSM da úlcera aumentou de 110 para 159 pós-tratamento com bota, atingindo 203 pós-cicatrização. Intervalos predominantes na úlcera: 41-153 pré-tratamento, 83\% dos pixels; 133-196 pós-bota, 80\%; 175-255 pós-cicatrização, 97\%. GSM da ferida subcutânea ao redor da úlcera aumentou de 117 a 137 pós-cicatrização, de $67 \%$ a 88\% dos pixels no intervalo 91-174 ( $p<0,001)$. CATIM quantificou evolução fotográfica de cicatrização de úlcera venosa comparada com pele adjacente.
\end{abstract}

Palavras-chave: insuficiência venosa; úlcera; fotografia; análise quantitative; cicatrização. 


\section{INTRODUCTION}

Chronic venous insufficiency (CVI) is a common disease that can result in complications of significant morbidity, such as ulcers. ${ }^{1}$ The high CVI prevalence directly affects many individuals' quality of life during the productive phase of their lives. ${ }^{2}$ Treatment alternatives must be adapted to the slow healing processes and frequent recurrences. ${ }^{3}$ The progress of ulcer treatment is documented photographically. One common variable quantified photographically is ulcer area. ${ }^{4,5}$ This report describes an adaptation of the technique for tissue characterization based on ultrasonography (CATUS) to arrive at tissue characterization by imaging, in this case photographic imaging (p-CATIM). CATUS has been applied to analyze abdominal aneurysms treated with endoprostheses, ${ }^{6}$ carotid and peripheral arterial atheromas, ${ }^{7-9}$ venous thrombosis, ${ }^{10}$ kidneys ${ }^{11}$ and lymphedema. ${ }^{12}$ In addition to providing measurements of area, $\mathrm{p}$-CATIM also revealed granulation in a diabetic ulcer. ${ }^{13}$

The main objective of this study was to determine whether $\mathrm{p}$-CATIM could describe the healing processes of a venous ulcer both qualitatively and quantitatively. P-CATIM was applied to 3 photos of a chronic venous ulcer taken pre-treatment, post Unna boot treatment and post healing. The photographic characteristics of the open-healed ulcer were compared with those of the adjacent skin.

\section{CASE DESCRIPTION}

The guidelines set out in the declaration of Helsinki were adhered to avoid patient identification. The patient was a 35 years-old woman who reported rupture of a varicose vein 15 days prior to the doctor's visit. The ruptured varicose vein, located in the medial, distal third of the right leg, developed into an ulcer (Figure 1). This shallow ulcer had regular edges and granulation tissue with hyperchromia. Induration cellulites was noted. The patient also stated that the leg had been swollen and red prior to occurrence of the lesion. She sought medical attention because of concern that the wound was not healing. Pain was not reported. Odor was not detected.

Clinical history included leg tiredness since age 19 and varicose vein surgery at 21 . Venous symptoms, however, persisted and got worse after her second pregnancy, at age 27 . The patient did not take contraceptives. She was taking Flavonid without medical prescription to treat leg tiredness, but stopped the medication once the wound appeared.

Physical examination demonstrated normal heart, $120 \times 80 \mathrm{mmHg}$ blood pressure, normal carotid and peripheral pulses, and hyperpigmentation in the distal third of the leg. Treatment included Duoflan. Secretion was minimal. Unna boots were applied a total of 3 times every 15 days. The patient used elastic stocking.

\section{P-CATIM TECHNIQUE}

Figure 2 shows photographs obtained pre-treatment, post Unna boot treatment, and post healing. These photos were analyzed using a p-CATIM technique adapted from CATUS. Each image was reformatted to gray scale with 256 levels of brightness amplitude. Differences between photos were minimized by re-scaling. The actual gray brightness per pixel was recalculated to fit a new scale along which black
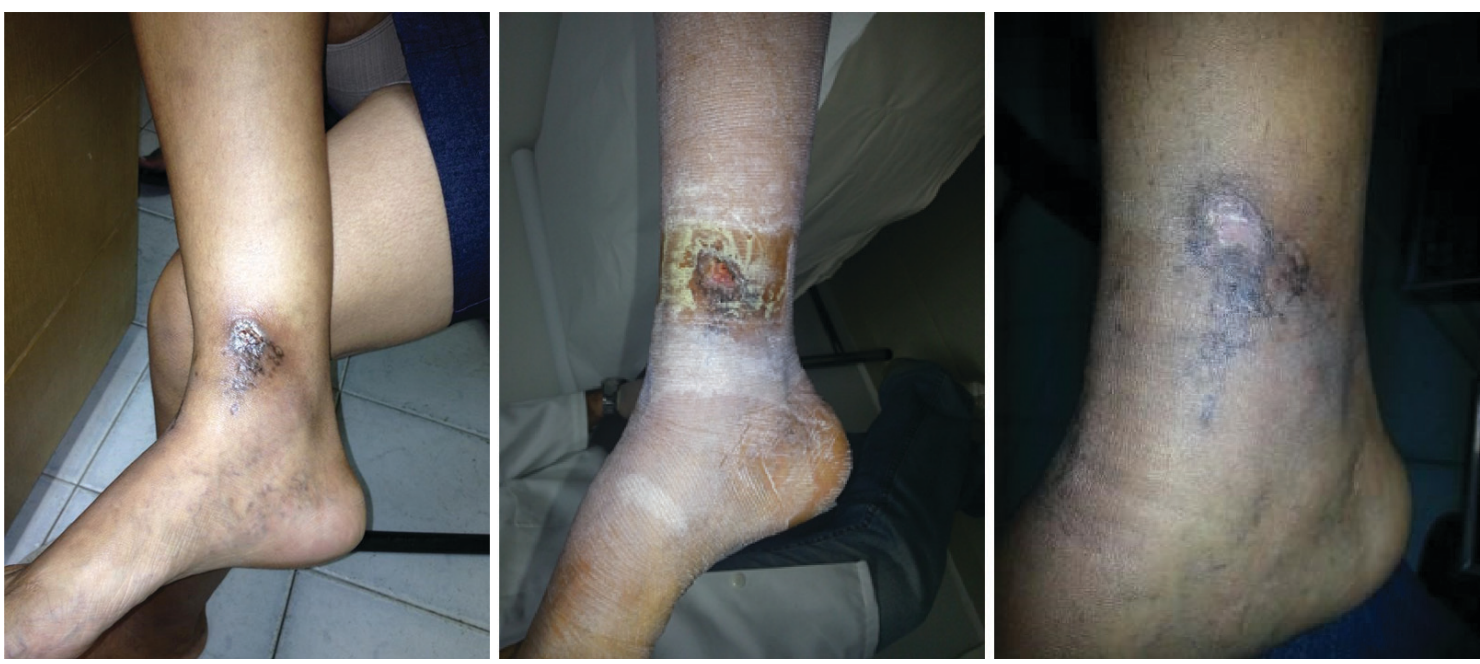

Figure 1. Photographs of venous ulcer, taken pre-treatment, post Unna boot treatment and post healing. 
equated to 0 and skin adjacent to the ulcer equated to 200. Gray scale medians (GSM) were calculated for each specific region selected in the photos. The percentages of pixels in each of 14 brightness amplitude intervals were estimated. Table 1 lists the intervals and the percentages of pixels that fell into each interval.

Ulcer GSM increased from 110 pre-treatment to 159 post Unna boot treatment, reaching 203 post healing. This 203 was similar to the 200 value ascribed to the adjacent skin. Therefore, the GSM increased from $55 \%(110 / 200)$ to $80 \%(159 / 200)$ of the skin value post Unna boot treatment, reaching similar skin brightness post healing (203/200).

Analysis of intervals with $10 \%$ increments in pixels demonstrated shifts in brightness as follows. Pre-treatment, the open ulcer had $83 \%$ of pixels in the 41-153 brightness interval. The brightness level increased post Unna boot treatment, by which point $80 \%$ of pixels fell in the 133-196 interval. Post healing, $97 \%$ of pixels had brightness within the interval 175-255. These proportions of pixels within distinct brightness intervals were different with statistical significance $(\mathrm{p}<0.05$ by Chi-square).

The subcutaneous wound around the healed ulcer, however, continued to have lower brightness than the adjacent skin. The GSM of the subcutaneous wound increased from 117 pre-treatment to 137 post healing. The most common brightness interval of the subcutaneous wound post healing was 91-174. The percentage of pixels within this interval increased from $67 \%$ pre-treatment to $88 \%$ post healing.

Quality control included analysis of the original brightness of the adjacent skin (Table 1), which was

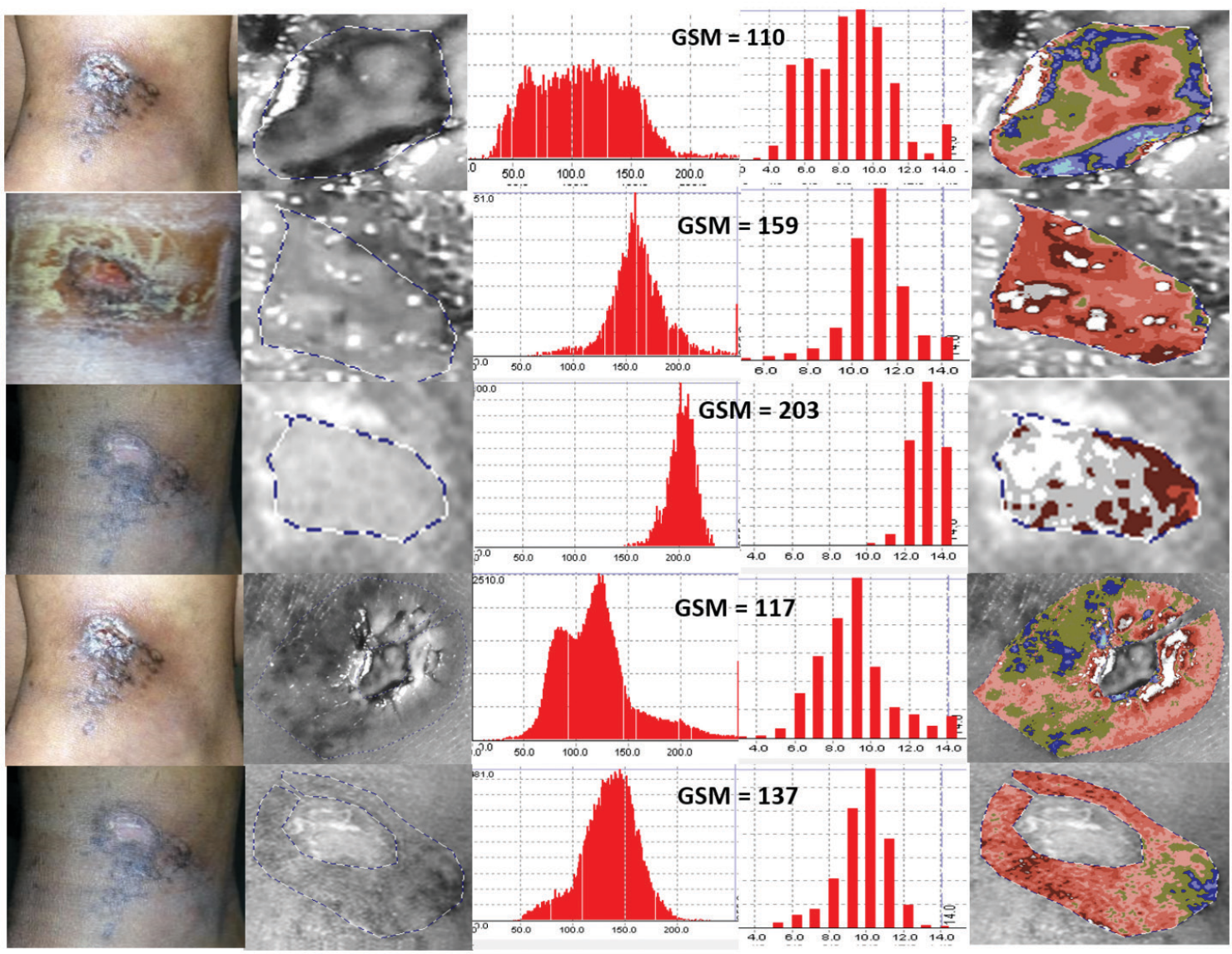

Figure 2. Characterization of tissue by photographic imaging (p-CATIM) of a venous ulcer of the leg. Three photos obtained pre-treatment, post Unna boot treatment and post healing. Additional analyses of subcutaneous wound pre-treatment and post healing. Column 1: original image. Column 2: image converted to gray scale with 256 levels of brightness amplitude. Column 3: histogram of number of pixels as a function of brightness. Column 4: bar histograms of percentages of number of pixels in each of 14 intervals of brightness amplitude. Gray scale median (GSM) depicted in between histograms. Column 5: ulcer and subcutaneous wound artificial colorization using 14 colors to represent brightness intervals. Relations between colors and brightness intervals are presented in Table 1. 
Table 1. Percentages of number of pixels in brightness amplitude intervals for photographs of a venous ulcer in the medial aspect of distal third of the leg: Images 1, 2, 3: ulcer pre-treatment, post Unna boot treatment and healed ulcer; Images 4, 5: subcutaneous wound around ulcer pre-treatment and post healing.

\begin{tabular}{|c|c|c|c|c|c|c|}
\hline \multirow{2}{*}{ Color } & \multirow{2}{*}{$\begin{array}{l}\text { Gray } \\
\text { Scale }\end{array}$} & \multicolumn{5}{|c|}{ Percentage of number of pixels per interval } \\
\hline & & Image 1 & Image 2 & Image 3 & Image 4 & Image 5 \\
\hline & GSM & 110 & 159 & 203 & 117 & 137 \\
\hline & $0-4$ & 0.0 & 0.0 & 0.0 & 0.0 & 0.0 \\
\hline & $5-7$ & 0.0 & 0.0 & 0.0 & 0.0 & 0.0 \\
\hline & $8-26$ & 0.1 & 0.0 & 0.0 & 0.02 & 0.0 \\
\hline & $27-40$ & 1.5 & 0.0 & 0.0 & 0.3 & 0.0 \\
\hline & $41-60$ & 11.1 & 0.02 & 0.0 & 1.5 & 0.8 \\
\hline & $61-76$ & 11.7 & 0.4 & 0.0 & 7.7 & 2.5 \\
\hline & $77-90$ & 10.5 & 1.1 & 0.0 & 14.3 & 3.6 \\
\hline & $91-111$ & 16.8 & 2.2 & 0.0 & 20.9 & 10.2 \\
\hline & $112-132$ & 17.5 & 6.8 & 0.0 & 28.1 & 25.2 \\
\hline & $133-153$ & 15.5 & 26.5 & 0.2 & 12.4 & 33.8 \\
\hline & $154-174$ & 8.8 & 37.4 & 2.5 & 5.2 & 18.7 \\
\hline & $175-196$ & 1.9 & 15.8 & 27.4 & 4.0 & 4.7 \\
\hline & $197-210$ & 0.6 & 5.1 & 44.4 & 2.0 & 0.3 \\
\hline & $211-255$ & 4.0 & 4.7 & 25.5 & 3.6 & 0.1 \\
\hline & $41-153^{*}$ & $83 \%^{*}$ & $37 \%$ & $0 \%$ & & \\
\hline & $133-196^{*}$ & $26 \%$ & $80 \%^{*}$ & $30 \%$ & & \\
\hline & $175-255^{*}$ & $6 \%$ & $26 \%$ & $97 \% *$ & & \\
\hline & $77-153^{*}$ & & & & $76 \% *$ & $73 \%$ \\
\hline & $91-174^{*}$ & & & & $67 \%$ & $88 \% *$ \\
\hline Quality Control & $200^{* *}$ & 153 & 133 & 159 & 151 & 166 \\
\hline
\end{tabular}

GSM: gray scale median. *Predominant intervals with $>10 \%$ of number of pixels in bold face. **Original brightness values for the skin adjacent to the ulcer, selected as reference 200.

then set as 200 on the p-CATIM common scale. The lowest skin brightness was 133, observed in the post Unna boot treatment photograph. This value of 133 was $25 \%$ smaller than the maximum skin brightness obtained from the other images. The coefficient of variability (mean/standard deviation) of the other 4 values was only $4 \%$.

In summary, p-CATIM showed that the healed ulcer or its new skin became photographically similar to the adjacent skin; but the cutaneous wound continued to be different photographically, with lower brightness.

\section{DISCUSSION}

Human eye physiology perceives, on average, 16 shades of gray, which is 16 times fewer than the 256 levels commonly found in ultrasonographic images. ${ }^{14}$ Software developed to characterize and differentiate gray scales increases visual perception and allows quantitative monitoring of medical conditions. Artificial colorization calls the attention of the observer to specific intervals. Quantification is based on calculation of the number of pixels per brightness interval.
This discovery level analysis has extended the CATIM technique to evaluation of venous ulcer healing. P-CATIM has previously documented photographic changes in a diabetic foot ulcer ${ }^{13}$ and has been applied to thermographic images of a) the shoulders of a patient with acute thrombosis of a subclavian vein, ${ }^{15}$ and b) neurogenic isquemia of the lower extremities. ${ }^{16}$ Presently, the CATIM method minimizes variations by recalculating brightness amplitudes to fit a scale with standardized brightness at the 0 and 200 levels. In this case, the adjacent skin was the reference for the 200 brightness level. In retrospect, this re-scale was needed to correct brightness differences of the image obtained post Unna boot treatment. The constancy of skin brightness around 150, however, indicates that the CATIM software should have variable options for re-scaling. Intervals employed in this application were described in the literature. ${ }^{6-13}$ Even without specific intervals for the venous ulcer evaluated, this study detected significant brightness changes after treatment. In particular, the GSM of the open ulcer acquired had, post healing, brightness similar to the adjacent skin. P-CATIM demonstrated that healed skin 
was similar, but found evidence of abnormalities in to the subcutaneous wound.

\section{CONCLUSION}

This analysis has extended applications of the CATIM/CATUS technique for enhanced perception and quantification of medical images. Photographic CATIM allowed quantifications related to the treatment of a chronic venous ulcer. Medical information has thus been expanded qualitative and quantitatively. Sequential analyses may indicate potential to continue or adapt treatments.

\section{REFERENCES}

1. França LHG, Tavares V. Insuficiência venosa crônica: uma atualização. J Vasc Bras. 2003;2(4):318-28.

2. Santos RFFN, Porfírio GJM, Pitta GBB. A diferença na qualidade de vida de pacientes com doença venosa crônica leve e grave. J Vasc Bras. 2009;8(2):143-7. http://dx.doi.org/10.1590/ S1677-54492009000200008.

3. Abbade LPF, Lastoria S. Abordagem de pacientes com úlcera da perna de etiologia venosa. An Bras Dermatol. 2006;81(6):509-22. http://dx.doi.org/10.1590/S0365-05962006000600002.

4. Samad A, Hayes S, French L, Dodds S. Digital imaging versus conventional contact tracing for the objective measurement of venous leg ulcers. J Wound Care. 2002;11(4):137-40. http://dx.doi. org/10.12968/jowc.2002.11.4.26385. PMid:11998594.

5. Griffin JW, Tolley EA, Tooms RE, et al. A comparison of photographic and transparency-based methods for measuring wound surface area. Phys Ther. 1993;73(2):117-22. PMid:8421717.

6. Salles-Cunha SX. Nota técnica: avaliação ultrassonográfica de aneurismas da aorta tratados com endopróteses. J Vasc Bras. 2012;11(2):150-3.

7. Lal BK, Hobson RW 2nd, Hameed M, et al. Noninvasive identification of the unstable carotid plaque. Ann Vasc Surg. 2006;20(2):167-74. http://dx.doi.org/10.1007/s10016-006-9000-8. PMid:16572292.

8. Menezes FH, Silveira TC, Silveira SAF, et al. Comparações preliminares entre a histologia virtual ultrassonográfica in vivo e os achados histopatológicos da placa carotídea produto de endarterectomia. J Vasc Bras. 2013;12(3):193-201. http://dx.doi. org/10.1590/jvb.2013.038.

9. Marks NA, Ascher E, Hingorani AP, et al. Gray-scale median of the atherosclerotic plaque can predict success of lumen re-entry during subintimal femoral-popliteal angioplasty. J Vasc Surg. 2008;47(1):109-16, discussion 115-6. http://dx.doi.org/10.1016/j. jvs.2007.09.039. PMid:18178460.

10. Cassou-Birckholz MF, Engelhorn CA, Salles-Cunha SX, et al. Assessment of deep venous thrombosis by grayscale median analysis of ultrasound images. Ultrasound Q. 2011;27(1):55-61. http://dx.doi.org/10.1097/RUQ.0b013e31820e157d. PMid:21343802.

11. Valiente Engelhorn AL, Engelhorn CA, Salles-Cunha SX, et al. Ultrasound tissue characterization of the normal kidney. Ultrasound Q. 2012;28(4):275-80. http://dx.doi.org/10.1097/ RUQ.0b013e318276f12b. PMid:23149511.

12. Salles-Cunha SX, Silveira AFS, Menezes FH. Ultrasound virtual histology to grade treatment of lower extremity lymphedema.
In: Poster presented at 36th SVU Annual Conference; 2012 June 7-9; National Harbor, MD. Society of Vascular Ultrasound; 2012.

13. Pereira VHH, Costa Filho EM, Santos FTA, et al. Caracterização tecidual de imagem fotográfica durante tratamento do pé diabético ulcerado: nota técnica. J Vasc Bras. 2013;12(4):303-7. http://dx.doi. org/10.1590/jvb.2013.060.

14. Beach KW, Paun M, Primozich JF. Principles and instruments of diagnostic ultrasound and doppler ultrasound. In: Aburahma AF, Bergan JJ, editors. Noninvasive vascular diagnosis: a practical guide to therapy. 2nd ed. London: Springer-Verlag; 2007. p. 27.

15. Salles-Cunha SX, Oliveira HV, Guimarães AF. Valor complementar da termografia no diagnóstico de trombose da veia subclávia: relato de caso. In: Pôster apresentado em: $40^{\circ}$ Congresso da Sociedade Brasileira de Angiologia e Cirurgia Vascular; 2013 Set 5; Florianópolis, SC. Florianópolis: SBACV; 2013.

16. Salles-Cunha SX, Oliveira HV. Termografia complementa ultrassonografia arterial e medida de pressões distais em caso de isquemia neurovascular do pé diabético dolorido. In: Pôster apresentado em: $40^{\circ}$ Congresso da Sociedade Brasileira de Angiologia e Cirurgia Vascular; 2013 Set 5; Florianópolis, SC. Florianópolis: SBACV; 2013.

Correspondence Camila Ataíde Rocha Universidade Estadual de Ciências da Saúde de Alagoas - Uncisal Rua Santos Pacheco, 28 - Centro CEP 57020-290 - Maceió (AL), Brazil Tel.: + 55 (82) 9931-0542

E-mail: camilaataide1@gmail.com

Author information FTAS - Medical student at Universidade Estadual de Ciências da Saúde de Alagoas (Uncisal) CAR - Medical student at Universidade Estadual de Ciências da Saúde de Alagoas (Uncisal).

TFAS - Medical student at Universidade Estadual de Ciências da Saúde de Alagoas (Uncisal).

CHMJ - Medical student at Universidade Estadual de Ciências da Saúde de Alagoas (Uncisal). JMBL - Medical student at Universidade Estadual de Ciências da Saúde de Alagoas (Uncisal).

AMBC - Medical student at Universidade Estadual de Ciências da Saúde de Alagoas (Uncisal).

SXSC - Consultant in Noninvasive Vascular Diagnostic Techniques,

Ultrasonography and Research, Honorary member, Sociedade Brasileira de Angiologia e Cirurgia Vascular (regional offices in Santa Catarina and Espírito Santo), Asociacion Colombiana de Angiologia y Cirugia Vascular, and Society for Vascular Ultrasound.

GBBP - Adjunct professor of Surgery at Universidade Estadual de Ciências da Saúde de Alagoas (Uncisal).

Author contributions Conception and design: SXSC Analysis and interpretation: SXSC, CHMJ Data collection: FTAS, CHMJ, AMBC Writing the article: CAR, SXSC, JMBL Critical revision of the article: CAR, JMBL, FTAS, TFAS Final approval of the article*: FTAS, CAR, SXSC, TFAS, CHMJ, JMBL, AMBC, GBBP Statistical analysis: TFAS, SXSC, GBBP Overall responsibility: GBBP

*All authors should have read and approved of the final version of the article submitted to J Vasc Bras. 